\title{
Biosensor Recognition Elements
}

James P. Chambers ${ }^{1, *}$, Bernard P. Arulanandam ${ }^{1}$, Leann L. Matta ${ }^{2}$, Alex Weis ${ }^{3}$, and James J. Valdes ${ }^{4}$

${ }^{1}$ Department of Biology, The University of Texas at San Antonio, San Antonio, TX 78249, ${ }^{2}$ Fischell Department of Bioengineering, Chemical and Nuclear Engineering, University of Maryland, MD 20742, ${ }^{3}$ OncoVista, Inc., San Antonio, TX 78245, ${ }^{4}$ Office of the Scientific Advisor for Biotechnology, Aberdeen Proving Ground, MD 21010, USA

\section{Introduction}

Molecular recognition is central to biosensing. Since the first biosensor was developed by Updike and Hicks (1967) many biosensors have been studied and developed. As shown in Fig. 1, a biosensor can be defined as a "compact analytical device or unit incorporating a biological or biologically derived sensitive 'recognition' element integrated or associated with a physio-chemical transducer" (Turner, 2000). Initially, biosensor recognition elements were isolated from living systems. However, many biosensor recognition elements now available are not naturally occurring but have been synthesized in the laboratory. The sensing of targets, i.e. analytes of interest, is already being influenced by the emergence of engineered binding proteins (Feltus and Daunert, 2002). Employing the techniques of modern biotechnology, it is now possible to construct DNA polynucleotides at will, thus opening new paths for generation of biosensor recognition elements arising from paths not taken by nature. The following review is restricted to a selective overview of molecular recognition elements, including receptors, enzymes, antibodies, nucleic acids, molecular imprints and lectins currently impacting biosensor development (Fig. 1). With the advent of nanostructures and new interface materials, these recognition elements will be major players in future biosensor development. "Transduction" of the biorecognition event constitutes a separate and obviously important area of biosensor development beyond the scope of the present review.

\section{Receptors}

For purposes of biosensing, receptors are alluring because of their generic "receiving" as well as "sending" functions. In addition to their being mediators of physiological processes, receptors are natural targets for a variety of toxins as well as drugs. Receptors are transmembrane (plasma and intracellular membranes) and soluble proteins that bind to specific molecules called ligands, the binding event initiating a specific cellular response. Ligand-induced receptor conformational changes give rise to subsequent events such as channel opening, adenyl/guanyl cyclase mediated second messenger generation, and reaction cascades involving a multitude of other proteins, including $\mathrm{G}$ proteins, tyrosine kinases, phosphatases, phosphorylases, transcription factors, and antigen processing cell receptor responses all constituting "transduction" in response to the initial ligand binding event.

Early on, Valdes and coworkers recognized the usefulness of receptor preparations as biosensor sensing elements for a variety of ligands of interests (Valdes et al., 1988; 1990). Although receptor preparations are attractive biosensor recognition elements due to high ligand specificity and affinity, their low yield and relative instability, labor intensive isolation and lengthy purification protocols of membrane associated proteins, as well as transduction difficulties have significantly impeded pursuit of receptor mediated sensing. However, with the advent of recombinant techniques and a multitude of expression systems, generation of large amounts of receptor protein is now possible, alleviating many of earlier logistical issues. Direct monitoring of receptor-ligand interaction was challenging due to absence of signal amplification associated with other sensor biorecognition elements, for example, enzyme recognition elements. However, the more recent development of very sensitive, direct monitoring of the binding event is now possible using surface plasmon resonance (Subrahmanyam et al. 2002).

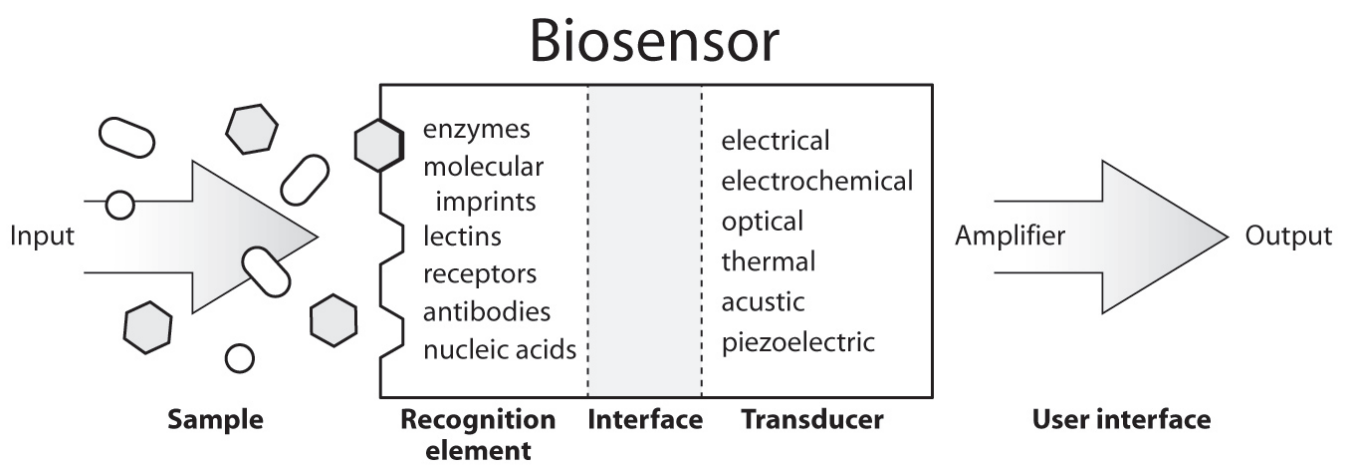

Fig. 1 Configuration of a biosensor showing biorecognition, interface, and transduction elements.

*For correspondence: James.Chambers@utsa.edu 


\section{Enzyme based recognition}

Catalytic enzyme based sensor recognition elements are very attractive for biosensor applications due to a variety of measurable reaction products arising from the catalytic process, which include protons, electrons, light, and heat. The enzyme urease has been widely used as a sensor biorecognition element due to a need for urea determination/monitoring for both medical and environmental applications (Barhoumi et al., 2006).

The very apparent inherent, regulatory nature of allosteric enzymes affords great potential for use as biosensor recognition elements. The regulatory subunit functions as the recognition element affecting, either in positive or negative fashion via conformational changes, the catalytic site serving as the transducing element (O'Connell and Guilbault, 2001). Although very attractive, allosteric proteins are multimeric in nature, presenting stability as well as expression difficulties. However, Villaverde and coworkers have successfully engineered catalytic proteins exhibiting sensing elements in the form of specific ligand binding sites which, in allosteric fashion, affect the respective catalytic events in response to different effectors (O'Connell and Guilbault, 2001). An engineered enzyme biorecognition element has been used for detection of HIV antibody in serum entailing two overlapping epitopes (P1 and P2 from the gp41 envelope glycoprotein) inserted adjacent to $\beta$-galactosidase active site resulting in a hybrid enzyme (Ferrer-Miralles et al., 2001). A number of engineered allosteric catalytic biorecognition elements are now available and include $\beta$-galactosidase, alkaline phosphatase, $\beta$-lactamase, and neural protease (O'Connell and Guilbault, 2001).

In similar fashion, green fluorescent protein (GFP) is now used in many "allosteric-like" sensing element applications. Because the fluorophore is an intrinsic part of the GFP polypeptide chain, no covalent modification of the protein is required. Numerous sensor applications involving use of GFP have been described (Doi and Yanagawa, 1999). Doi and Yanagawa have made hybrid fusion GFP containing specific molecular recognition sites by inserting protein domains containing the desired molecular recognition, binding site into a GFP surface loop. Random mutation of the ligand specific fusion protein insert gives rise to a combinatorial library from which binding of specific analytes can be selected via changes in fluorescence arising from the binding event (Doi and Yanagawa, 1999).

Of all enzyme recognition element based biosensors, the glucose biosensor is the most widely studied and acclaimed sensor success story. The importance and success of the glucose biosensor stems from the clinical relevance of diabetes, with 17 million people in the US alone afflicted with this life-long and as yet incurable disorder. Thus, the medical need for glucose monitoring has resulted in intensive efforts to develop glucose sensors and, of particular note, development of implantable electrochemical glucose sensors (Heller, 1999); bloodless glucose measurement (Roe and Smoller, 1998); microfabricated electrophoresis chips (Wang et al., 2000); needle microsensing (Wang, and Zhang, 2001); and engineered protein mediated sensing (Yamazaki et al., 2000).
Glucose monitoring is in reality no trivial task. Most monitoring of glucose is not a measure of blood glucose directly but one reflective of glucose levels in the interstitial fluid of subcutaneous tissue. The ratio of blood glucose (BG) to interstitial glucose (IG) is close to unity as long as the glucose concentration is not changing rapidly; otherwise one is dealing with a complicated interplay of glucose physiology and insulin kinetics. Not surprisingly, sensing of glucose can be most difficult in the "hypoglycemic" range where the greatest accuracy is demanded.

Although a variety of glucose sensors are available, the glucose biosensor has changed little in principle over the years. As shown in Fig. 2, glucose encounters an immobilized enzyme and transduction is achieved amperometrically via an electrode. Currently, most glucose biosensors utilize glucose oxidase as their recognition element that catalyzes the oxidation of glucose to gluconolactone:

glucose $+\mathrm{O}_{2} \rightarrow$ gluconolactone $+\mathrm{H}_{2} \mathrm{O}_{2}$

If oxidation is accomplished using glucose dehydrogenase ( $\mathrm{NAD}^{+}$prosthetic group), $\mathrm{NADH}$ is produced rather than $\mathrm{H}_{2} \mathrm{O}_{2}$. In the above reaction scheme, the dominant detection approach is electrochemical in nature where the product (hydrogen peroxide or $\mathrm{NADH}$ ) is electrochemically detected by an electrochemical mediator, e.g. organic dyes such as Prussian Blue and inorganic redox couples which serve as electron sinks. An alternative transduction scheme involves the use of quinoprotein glucose dehydrogenase, which requires neither oxygen nor $\mathrm{NAD}^{+}$but orthoquinone cofactors to oxidize a wide variety of alcohols and amines to their corresponding aldehydes and ketones. The quinoprotein glucose dehydrogenase recognition element uses pyrroloquinoline quinone (PQQ) as a cofactor and is described below:

glucose $+P Q_{(\mathrm{ox})} \rightarrow$ gluconolactone $+\mathrm{PQQ}_{(\mathrm{red})}$

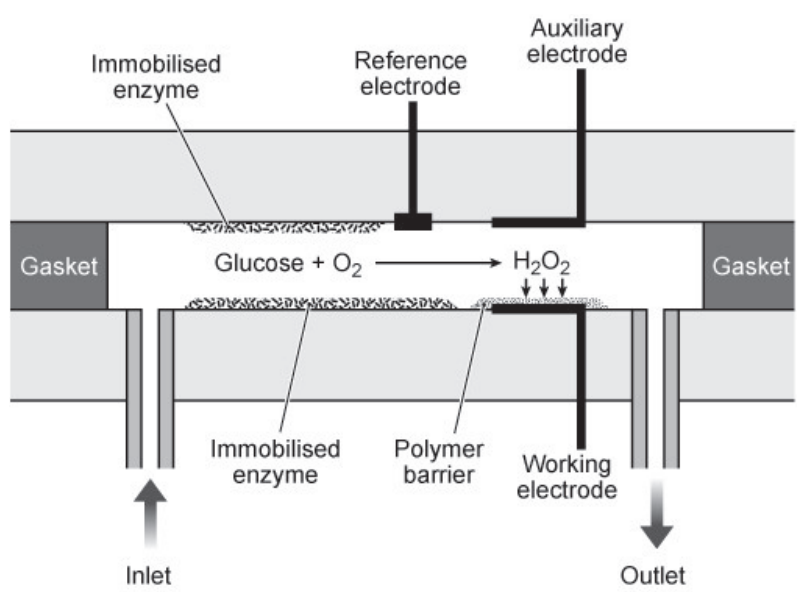

Fig. 2 Diagram of the glucose sensor showing the electrode configuration, the polymer barrier deposited onto the working electrode, and the surface where the enzyme (glucose oxidase) is immobilized. 
A novel and exciting improvement over that shown in Fig. 2 is that of a molecular "wired" enzyme recognition element based glucose biosensor developed by Heller (1990). This sensor is comprised of enzymes (glucose and bilirubin oxidases) electrically wired with redox polymers I and II, respectively (Fig. 3). Interestingly, because $\mathrm{O}_{2}$ is a natural cosubstrate of glucose oxidase, it interferes with glucose assays. Thus, as the $\mathrm{O}_{2}$ partial pressure is increased, the anodic glucose electrooxidation current, (i.e. signal) decreases. As shown in Fig. 3 (center complex), the glassy carbon electrode which consists of cross-linked glucose oxidase (GOx) and redox polymer I is well shielded, and $\mathrm{O}_{2}$ is electroreduced. As configured, almost total electroreductive stripping of $\mathrm{O}_{2}$ from the solution near the glucose electrooxidizing anode is achieved so that residual reducible $\mathrm{O}_{2}$ no longer defines the detection limit. Mano and Heller have successfully detected glucose at femtomolar concentrations (Mano and Heller, 2005). Importantly, this molecular "wired" oxidase format can be used for detection of a variety of important analytes of clinical relevance such as lactate, L- $\alpha$-glycerolphosphate and glutamate.

Advances in the field of micro/nanoelectromechanical systems (MEMS/NEMS) now offer unique opportunities for extremely accurate, real time measurement of blood glucose. MEMS/NEMS have demonstrated unique advantages such as their small size and integration into a variety of devices. Among the MEMS platforms, microcantilevers have been proven to be an outstanding platform for chemical and biological sensors, with detection limits as low as femtomolar (Tang et al., 2004). Modified microcantilevers can recognize target molecules through specified biological binding which results in deflection of the cantilever. Yan and coworkers have devised a glucose oxidase functionalized microcantilever for detection of glucose (Yan et al., 2005).

Carbon nanotubes are hollow graphitic structures and are promising for immobilization purposes because of their significant mechanical strength, high surface area, excellent electrical conductivity and chemical stability. The lengths of the nanotubes can range from several hundred nanometers to several micrometers and the diameter ranges from 0.2 to 2 nanometers for single walled structures, and 2 to 100 nanometers for coaxial multiwalled structures. The subtle electronic properties of carbon nanotubes are not only attractive with regard to the

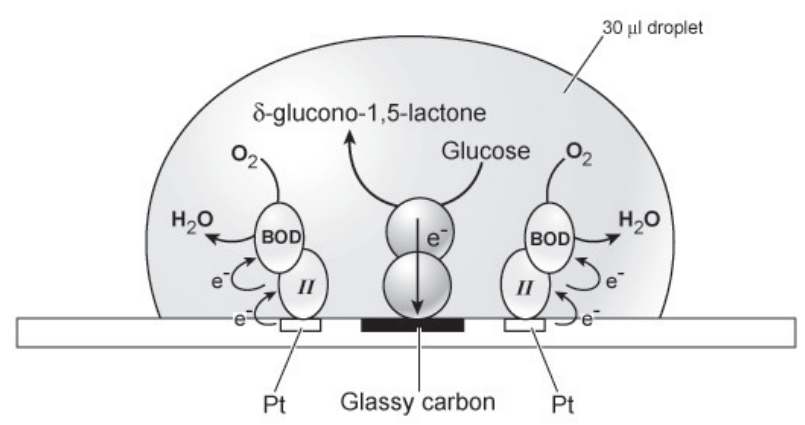

Fig. 3 Schematic diagram of glucose detection by electrooxidation on a stationary glassy disk with electrically "wired" glucose and bilirubin oxidases. development of "wired" enzyme biorecognition elements but also sensitive determination of physiologically important peptides such as insulin (Zhang et al., 2005). Current wired enzyme and peptide sensors are the forerunners of nanowired arrays that can result in exquisite sensitivity because they are so small that when an analyte binds at the surface of the recognition element, the entire nanowire is affected (Hitt, 2004).

In contrast to catalytic schema, binding of substrate such as glucose without catalysis is ideal because substrate-depletion effects, in this case reduction of substrate concentration, are problematic due to "mass law" considerations. If the binding event is made the sole basis for detection, then little analyte is consumed, avoiding depletion effects arising from catalytic conversion to product. Importantly, such configurations lead to significantly smaller sensing elements which in turn can be arrayed at significantly higher density than that for substrate to product based sensing. Non-catalytic based sensing of glucose had its origins in the work of Schultz and coworkers based upon fluorescence resonance energy transfer (FRET) between a donor and acceptor following binding of glucose to glucose binding proteins (Schultz, and Sims, 1979) but found very limited use due to reversibility and aggregation problems. More recently, thermostable glucose binding proteins from Aspergillus niger (glucose oxidase), Thermoplasma acidophilum (glucose dehydrogenase) and Bacillus stearothermophilus (glucokinase) have been engineered to report via fluorescence and/or fluorescence energy transfer the binding of glucose in a non-consuming manner where glucose is bound but not chemically converted to product (Scognamiglio et al. 2004). Bambot and coworkers have suggested that implanted, reversible, non-consuming glucose sensing could potentially be achieved through the skin using red laser diodes or light emitting diode devices as the light source (Bambot et al., 1995). Importantly, the use of inactive apoenzymes for reversible sensing greatly simplifies the sensing platform as well as expands the range of metabolically important proteins that can be used as sensor biorecognition elements.

\section{Antibody based recognition}

With the notable exception of the glucose sensor, the majority of rapid detection systems employ antibodies for recognition, identification and quantitation of target analytes. Antibodies have been used extensively for detection purposes; however, their popularity increased significantly following Kohler and Milstein's seminal work establishing monoclonal antibody (MoAb) technology (Jayasena, 1999). Using cell clones that specifically produce MoAbs of choice, large quantities of antibody can now be produced. Antibody recognition elements make use of the sensitivity and specificity of bimolecular antibody-antigen interactions. The major advantage of antibody sensor biorecognition elements is that the immunogen, i.e. target, need not be purified prior to detection. A variety of signal transduction (optical and electrochemical) techniques have been developed and the most useful has been enzyme-fluorescence based with catalytic turnover resulting in amplification of signal, thus increasing the sensitivity of the assay. 
Like many routinely used diagnostic assays, the majority of current PSA (prostate-specific antigen) assays are variations of enzyme-linked immunosorbent assays (ELISA) reporting via the specific formation of PSA immune complex. Wu and coworkers' (2001) observation of nanomechanical motion generated by protein ligand interactions on microcantilevers has led to immobilization of PSA antibody recognition element for detection of PSA in serum (Fig. 4). Molecules adsorbed on a microcantilever cause vibrational frequency changes referred to as "curling" due to adsorption stress on one side of the cantilever. Surface plasmon resonance based optical transduction by noble metals has also been used as basis of antibody recognition element assays (Hirsch et al. 2003). Such technology readily lends itself to wellestablished array microfabrication techniques, thereby offering the promising prospect of high throughput, biosensor based analysis of clinical samples.

Recombinant antibodies consisting of genetically manipulated fused antigen binding domains (Fab fragment) of common antibodies are now available (Emanuel et al., 2000). When compared to polyclonal or monoclonal antibodies, generation (expression and purification) of recombinant antibodies is less expensive and time consuming. A number of recombinant antibodies have been shown to be useful for detection and identification of HIV, Hepatitis B and C, Simian immunodeficiency, Ebola, Rabies, Epstein-Barr, and Measles viruses as well as biological agents such as botulinum neurotoxin A/B (O'Brien et al., 2001; Petrenko and Sorokulova, 2004). Benhar and coworkers have demonstrated the usefulness of carbon electrode immobilized single chain (scFvs) recombinant antibodies specific for Listeria monocytogenes, and the MtKatG enzyme expressed by Mycobacterium tuberculosis in an electrochemical biosensor (Benhar et al., 2001).

A clever marriage of the well-established polymerase chain reaction (PCR) nucleic acid detection methodology
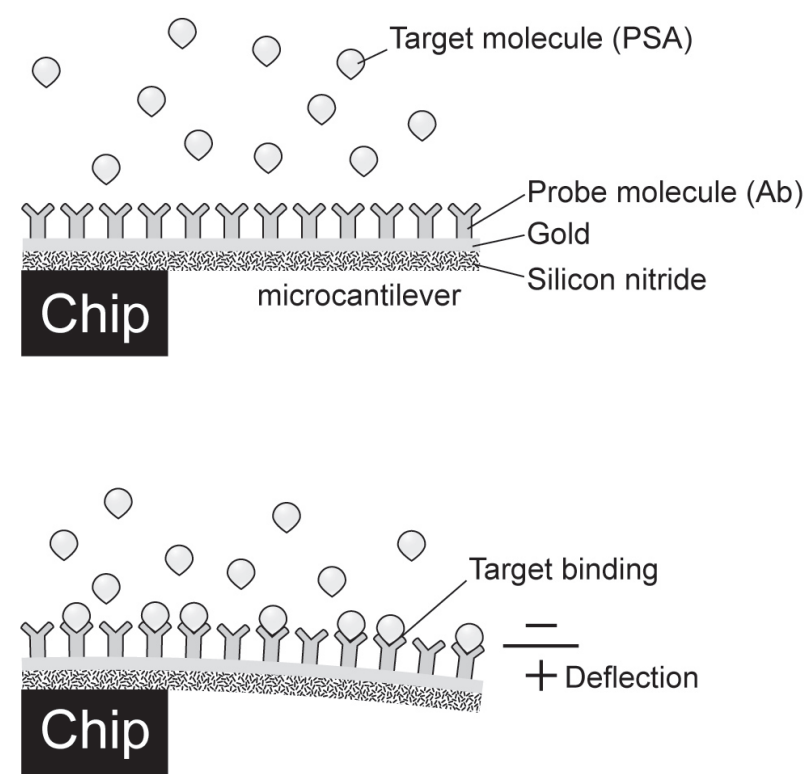

Fig. 4 Diagram of interactions between target and probe molecules on a microcantilever beam. to that of high-sensitivity immunodetection of proteins was achieved by establishment of immuno-PCR (Sano et al., 1992) resulting in detection of clinically relevant tumor markers, viral proteins, pathogens (microorganisms), toxins and metabolites (Niemeyer et al., 2005). ImmunoPCR takes advantage of specific, conjugated recognition elements comprised of an antibody and DNA marker fragment, combining the versatility of enzyme-linked immunosorbent assays (ELISAs) with the amplification power and sensitivity of the PCR (Fig. 5, Frame A). As a consequence, the limit of detection of a given ELISA is in general enhanced 100-10 000 fold by the use of PCR as a signal amplification system (Fig. 5, Frame B). Although Immuno-PCR is now a well-established technique for routine applications in both fundamental and clinical applied immunological research, to date the PCR step must be carried out using a PCR machine. However, miniaturized PCR devices using microfluidic channels and reaction chambers are now described in the literature (Koh et al., 2003; Gulliksen et al., 2004) making possible development of a "chip based" immuno-PCR biosensor. Additionally, DNA-DNA hybridization detection has been reported using cantilever based recognition elements which could be applicable to Immuno-PCR (Hansen et al., 2001; Wu et al., 2001).

Antibodies are currently being used in nontraditional immunoreagent mediated sensing schemes. One such

A

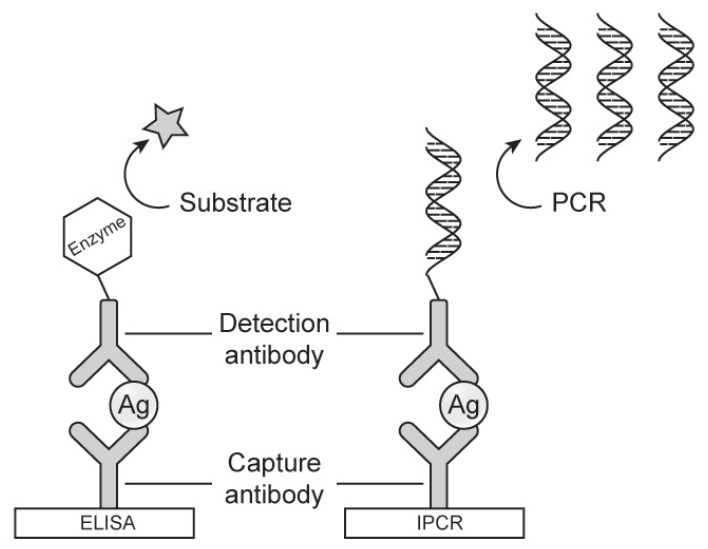

B

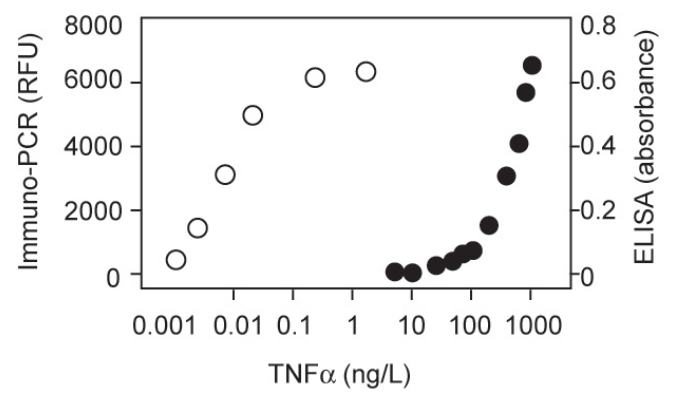

Fig. 5 General setup of immuno-PCR (IPCR) is similar to that of antigen (Ag) detection using ELISA. Frame A, Comparison of ELISA and IPCR. Frame B, Typical comparison of dose-response curves for ELISA (closed circles) and analogous IPCR (open circles). 
technology is that of the "ion channel switch" which involves a self-assembling synthetic biomembrane. This biosensing element is a two molecule layer, selfassembled membrane structure modeled after the ionchannel peptide gramicidin. The binding of target analyte to antibody tethered to the channel alters the population of conduction ion channel pairs within the membrane, resulting in a change in membrane conduction and an "on/ off" response resulting from channel closure or distortion (Krishna et al., 2003).

Another non-traditional but novel immunoreagent sensing scheme is that of antibody dendrimers (Yamaguchi and Harada, 2003). As shown in Fig. 6, the antibody dendrimer complex consists of an immunoglobulin core $(\lg \mathrm{M})$ and chemically modified $\lg \mathrm{G}$ branches. Addition of antibody to the divalent antigen-antibody complex immobilized on the sensor surface results in increased SPR signal intensity.

\section{Aptamer based recognition}

Biosensors using aptamers as biorecognition elements are referred to as aptasensors. Aptamers are nucleic acid ligands (RNA, ssDNA, modified ssDNA, or modified RNA) that are isolated from libraries of oligonucleotides by an in vitro selection process called SELEX (Systematic Evolution of Ligands by EXponential enrichment) (Ellington and Szostak, 1990; Tuerk and Gold, 1990). These DNA/RNA ligands are thought to recognize their target primarily by shape (i.e. conformation) and not sequence (Lim et al., 2005). Since they are short, singlestranded oligonucleotides, they are capable of folding into three-dimensional structures due to their self-annealing properties. Aptamers bind with high affinity and specificity to a broad range of target molecules, and have proven suitable for analytic and diagnostic applications (Luzi et al., 2003). Since aptamers are synthetically evolved in the SELEX process, their potential range of use is virtually unlimited. As shown in Fig. 7, a library of DNA oligonucleotides containing a portion of randomized sequence is synthesized. The library is then converted into dsDNA by PCR and into RNA by in vitro transcription using the T7 RNA polymerase. After incubation of the target analyte with the nucleic acid pool, the non-specific or low-affinity binding nucleic acid molecules are removed

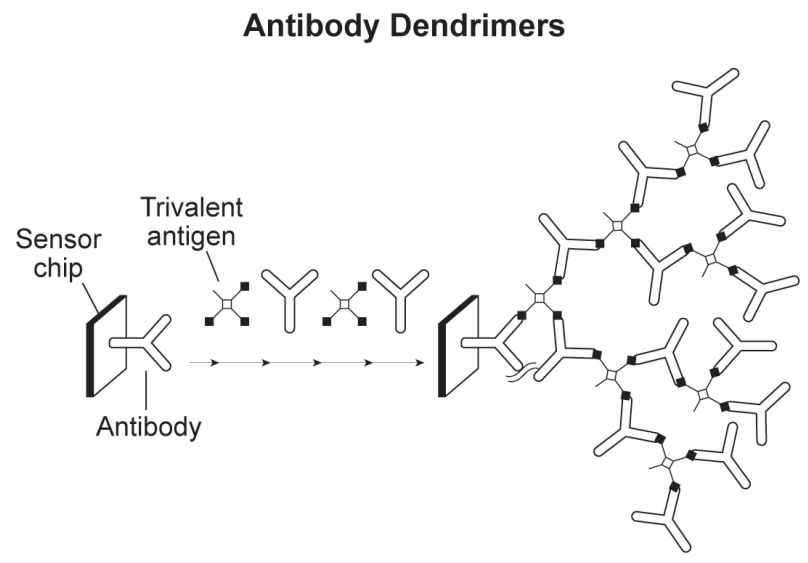

Fig. 6 A proposed structure of an antibody dendrimer complex.

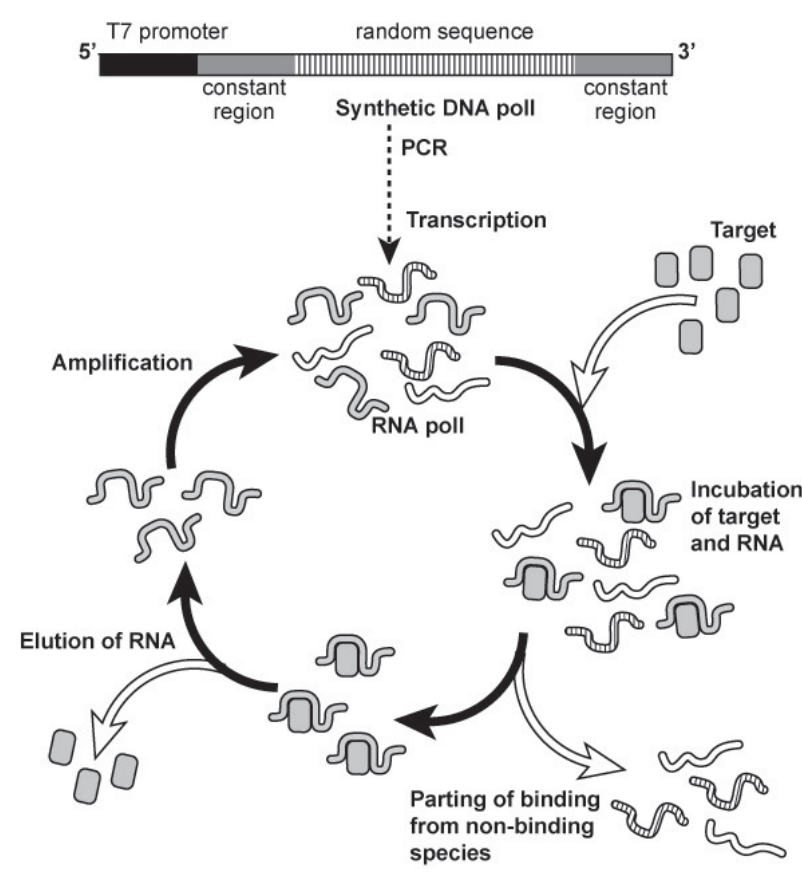

Fig. 7 Scheme of in vitro selection of an RNA aptamer (SELEX).

by washing steps and the captured RNA molecules are eluted, recovered and amplified by RT-PCR and subsequently transcribed back to RNA. The whole cycle is repeated until obtaining a specific population of high affinity binding RNA which is isolated and characterized.

Aptamers have been produced against a wide range of targets including small molecules, proteins and whole cells, making them very useful for detection purposes. These nucleic acid recognition elements are more flexible than their protein counterparts. Predominantly unstructured in solution, aptamers fold upon associating with their ligands into molecular architectures in which the ligand becomes an intrinsic part of the nucleic acid structure. Due to their high binding affinity, simple synthesis, easy storage, and wide applicability, aptamer sensor recognition elements are emerging as a new class of molecules that rival commonly used antibody biosensor recognition elements.

The efficacy of aptamers has been shown on a number of biosensing platforms. Stadtherr and coworkers have demonstrated the feasibility of a DNA aptamerbased biochip for protein detection ( $\lg E$ and specific anti-IgE antibodies) (Stadtherr et al., 2005). Cantilever surfaces have been functionalized with aptamers (Savran et al., 2004). Liss et al. (2002) reported labelfree detection of IgE using aptamers and a quartz crystal microbalance system. Detection of HIV-1 Tat protein (trans activator of transcription) has been achieved using RNA aptamer recognition element based quartz crystal biosensor (Minunni et al., 2004). Recently, Gronewold and coworkers (2005) devised an anti-thrombin aptamer surface acoustic wave (SAW) biosensor for monitoring blood-coagulation cascade complex formation.

Catalytic aptamers called aptazymes are relatively new to the recognition element theme and may prove especially useful for capturing and thus monitoring key 
metabolic intermediates of diagnostic value whose concentration might be very low (Hesselberth et al., 2003). Aptazymes (RNAzymes and DNAzymes) are aptamers possessing allosteric properties that transduce recognition of target analytes into catalytically generated observable signals. With the development of functionalized gold nanoparticles, DNAzymes have become especially attractive biosensor recognition elements because many analyte-dependent DNAzymes have been isolated (Table 1). DNAzymes may be very useful in monitoring diseases such as diabetes and Alzheimer's as well as chemical warfare agents due to pathopneumonic changes in metal ion concentrations. Also noteworthy, DNAzymes, like RNAzymes, can be repeatedly denatured without losing catalytic/binding abilities. Furthermore, DNA is relatively inexpensive to produce and can be easily derivatized. Aptazymes are easily engineered and can detect diverse classes of biologically relevant molecules from small organics to proteins, and their high signal-to-noise ratios make them ideal for array formats, which have been shown to apprehend and quantitate a wider range of analyte classes than would be possible with typical antibody-based sandwich assays (ELISA arrays) (Kirby et al., 2004).

A key development in aptamer-based sensors is that of "signaling or 'molecular beacon' aptamers," which have the ability to report directly following binding to their specific targets. Molecular beacons have become a class of DNA/RNA probes used in chemistry, biology, biotechnology and medical sciences for molecular recognition. However, this theme has now been adapted to a variety of nucleic acid formats including aptamers and nucleic acid peptides. These beacons act like switches that are normally closed or "off." Binding induces conformational changes that open the hairpin and, as a result, fluorescence is turned "on." The stem structure holds the fluorophore and the quencher in close proximity to one another, preventing the fluorophore from emitting a signal as a result of resonance energy transfer (Tyagi

Table 1 Various DNAzymes

\begin{tabular}{|c|c|c|c|}
\hline Reaction & Cofactor & $\mathrm{k}_{\max }\left(\min ^{-1}\right)^{\mathrm{a}}$ & $\mathrm{k}_{\text {cat }} \mathrm{k}_{\text {uncat }}$ \\
\hline \multirow[t]{7}{*}{ RNA transesterification } & $\mathrm{Pb}^{2+}$ & 1 & $10^{5}$ \\
\hline & $\mathrm{Mg}^{2+}$ & 0.01 & $10^{5}$ \\
\hline & $\mathrm{Ca}^{2+}$ & 0.08 & $10^{5}$ \\
\hline & $\mathrm{Mg}^{2+}$ & 10 & $>10^{5}$ \\
\hline & None & 0.01 & $10^{8}$ \\
\hline & L-Histidine & 0.2 & $10^{6}$ \\
\hline & $\mathrm{Zn}^{2+}$ & $\sim 40$ & $>10^{5}$ \\
\hline DNA cleavage & $\mathrm{Cu}^{2+}$ & 0.2 & $>10^{6}$ \\
\hline DNA ligation & $\mathrm{Cu}^{2+}$ or $\mathrm{Zn}^{2+}$ & 0.07 & $10^{5}$ \\
\hline RNA ligation & $\mathrm{Mn}^{2+}$ & 2.2 & $>10^{6}$ \\
\hline DNA phosphorylation & $\mathrm{Ca}^{2+}$ & 0.01 & $10^{9}$ \\
\hline $5^{\prime}, 5^{\prime}$-pyrophosphate formation & $\mathrm{Cu}^{2+}$ & 0.5 & $>10^{10}$ \\
\hline Porphyrin metallation & None & 1.3 & $10^{3}$ \\
\hline
\end{tabular}

a Reactions catalyzed by DNAzymes that were isolated from in vitro experiments. $\mathrm{k}_{\text {cat }} / \mathrm{k}_{\text {uncat }}$ is the rate enhancement over uncatalyzed reaction. and Kramer, 1996). Once the single stranded loop portion hybridizes to the target, the stem melts and the resulting spatial separation of the fluorophore from the quencher leads to an enhancement of fluorescence signal (Fig. 8). Molecular beacon aptamers have been made against clinically relevant molecules such as thrombin (Nutiu and Li, 2004). Of clinical relevance in diagnostic screening is the fact that it has been estimated that $60 \%$ of all humans will have been affected by gene mutations in their lifetime and biorecognition elements capable of differentiating between two target DNA sequences differing by only a single nucleotide (Wang et al., 2002) will contribute significantly to high-throughput mutation detection. Additionally, signaling aptamers have the ability to indicate the presence of non-nucleic acid analytes such as proteins and small organic compounds (Rajendran and Ellington, 2002) which make them very useful for general detection purposes.

Because the precise target binding sites and the conformational changes of the aptamers are generally unknown beforehand, it is not easy to design donor/ acceptor labeling strategies. Therefore, efforts have been made to develop alternative methods without aptamer labeling. Stojanovic and Landry (2002) developed a calorimetric aptamer sensor for cocaine using specific dyes which, when displaced by the analyte cocaine, result in attenuation of absorbance proportional to the concentration of cocaine added. Jiang and coworkers have successfully used 1 RNA and 2 DNA aptamers specific for three disease-related proteins of diagnostic importance, i.e. IgE, PDGF-BB and $\alpha$-thrombin (Jiang et al., 2004). The method is simple, with no need for aptamer recognition element immobilization, and takes advantage of a sensitive luminescence change upon aptamer-protein binding via a ruthenium phenazine molecular light switch. The Ru-(phen $)_{2}(\mathrm{dppz}) 2^{+}$"light switch" complex does not luminesce in aqueous solution. However, when bound to dsDNA, the interaction protects the phenazine nitrogen from water, leading to intense emission. Thus, the folded structures of the aptamers allow intercalation of $\left[\mathrm{Ru}(\text { phen })_{2}(\mathrm{dppz})\right] 2^{+}$resulting in luminescence which is blocked by aptamer binding to target protein.

The primary limitation of the use of aptamers, specifically RNA aptamers, as recognition elements is their sensitivity to pyrimidine specific nucleases that are abundant in biological fluids. However, specific chemical modification of the ribose ring at 2 -position (Pieken et al., 1991) of pyrimidine nucleotides ( 2 -amino and $2^{\prime}$ fluoro functional groups) results in significant stability and protection. Additionally, 2'-amino and 2'-fluoro CTP and UTP can be incorporated into in vitro transcribed RNA, thus modifications can be introduced directly into the combinatorial library.

The advantages of aptamer recognition elements also make them very attractive for biosensor array formats. Lee and Walt (2000) have adapted aptamers to high-density fiber-optic arrays. McCauley and coworkers have generated a small aptamer sensing array that relies on scanning fluorescence anisotropy measurements for detection of several proteins with relevance to cancer (inosine monophosphate dehydrogenase, IMPDH; 


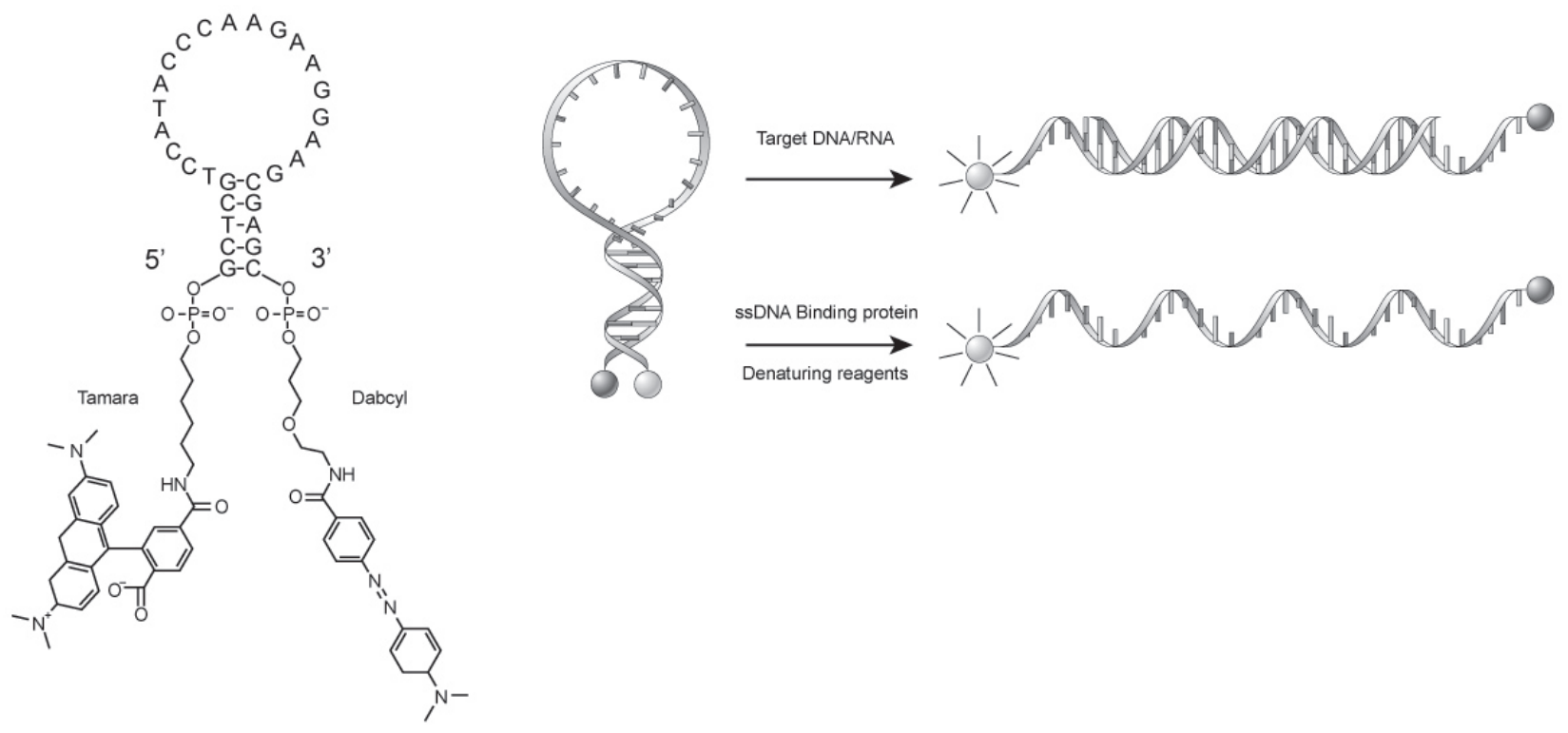

Fig. 8 Structural characteristics of molecular beacon probes. At the far left is shown a typical molecular beacon DNA probe. Shown to the right of the typical molecular beacon DNA probe is the molecular beacon working principle. The two spheres on the molecular beacon (center) represent quenched Tamara and Dabcyl moieties in contrast to unquenched, i.e. fluorescing (right).

vascular endothelial factor, VEGF and basic fibroblast growth factor, bFGF) (McCauley et al., 2003). Kirby and coworkers (2004) have integrated aptamer arrays with a device that could also deliver samples and perform complex assay procedures applicable to clinical sample sensing.

\section{Peptide nucleic acid based recognition}

Peptide nucleic acids (PNA) are synthetic DNA analogues or mimics with a polyamide backbone instead of a sugar phosphate bone (Egholm et al., 1993). Of significant importance to biosensing, PNAs exhibit superior hybridization characteristics and improved chemical and enzymatic stability compared to nucleic acids (Brandt and Hoheisel, 2004). Both double and triple stranded complexes are capable of being formed by PNA in association with nucleotides (Nakamura and Karube, 2003). As shown in Fig. 9, the negatively charged ribosephosphate backbone of nucleic acids is replaced by an uncharged $\mathrm{N}$-(2-aminoethyl)-glycine scaffold to which the nucleobases are attached via a methylene carbonyl linker. Because the intramolecular distances and configuration of the nucleobases are similar to those of natural DNA molecules, specific hybridization occurs between PNAs and cDNA or RNA sequences. The uncharged nature of PNAs is responsible for a better thermal stability of PNA-DNA duplexes compared with DNA-DNA equivalents and, as a result, single-base mismatches have a considerably more destabilizing effect (Egholm et al., 1993). As with DNA, the decrease in duplex stability depends on the position of the mismatch within the sequence (Igloi, 1998). The neutral amide backbone also enables PNA to hybridize to DNA molecules in lowsalt conditions because no positive ions are necessary for counteracting the interstrand repulsion that hampers duplex formation between two negatively charged nucleic acids. Consequently, the abundance and stability of intramolecular folding structures in the DNA or RNA analytes are significantly reduced, making the molecules more accessible to complementary PNA oligomers. Unlike

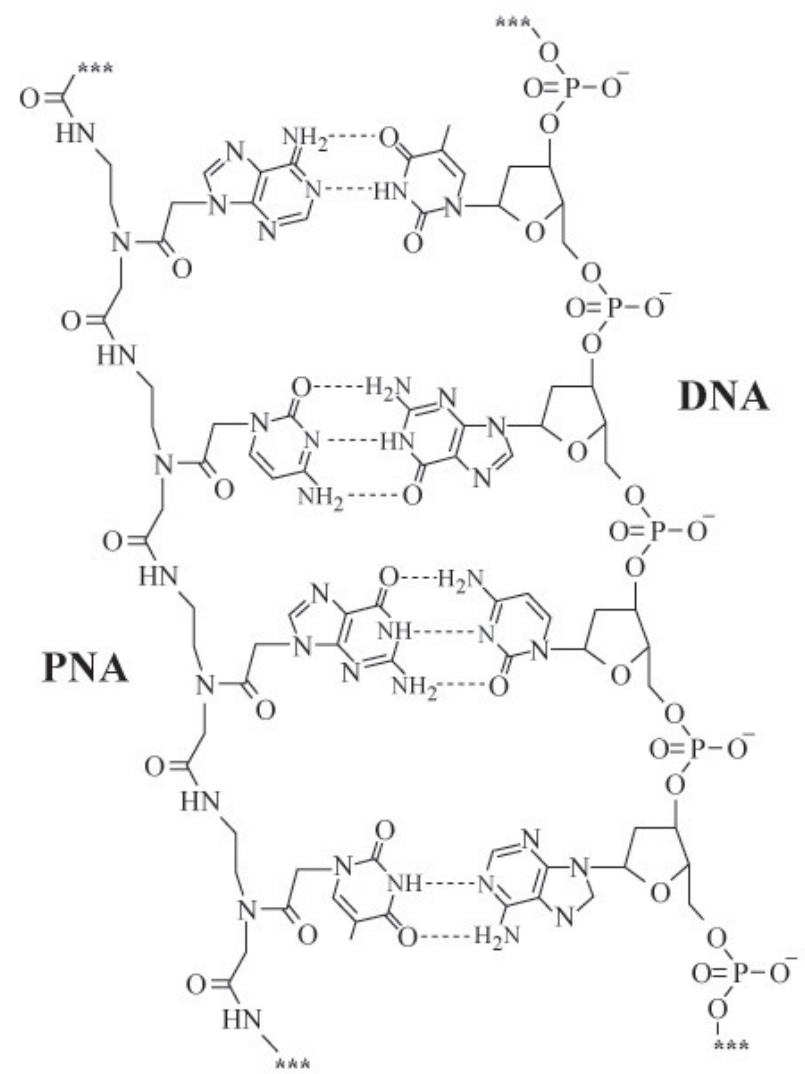

Fig. 9 Comparison of the structures of peptide nucleic acid (PNA) and DNA. 
DNA, which depurinates at acidic conditions, PNAs are stable across a wide range of temperatures and $\mathrm{pHs}$. Of significant importance in clinical samples, PNAs are resistant to nucleases and proteases (Demidov et al., 1994). In contrast to DNA molecular beacons, stemless PNA beacons are less sensitive to ionic strength and the quenched fluorescence of PNA is not affected by DNAbinding proteins. This enables the use of PNA beacons under conditions that are not feasible for DNA beacons.

The very different nature of PNA molecular structure enables new modes of detection, especially procedures that avoid the introduction of a label. Thus, the use of PNAs will contribute significantly to establishment of faster and more reliable biosensing applications. PNAs have now been used to replace DNA to functionalize gold nanoparticles (Chakrabarti and Klibanov, 2003) and, upon hybridization to complementary DNA strands and formation of nanoparticle aggregates, resulted in (1) a red-to-blue color transition and (2) high discrimination of DNA single-base mismatches. The change of color results from the shift of surface plasmon band (cf. aptamer based recognition) upon aggregation and this property is now the basis of colorimetric biosensors for selective detection of DNA. PNA functionized gold nanoparticles have been shown to be simple, highly sensitive and selective. Xi and coworkers (Xi et al., 2003) used DNA and PNA molecular beacons to detect and quantify rRNA in solution and in whole cells. Of clinical relevance, PNA molecular beacons are ideal tools for detection of whole bacteria in solution and in real time (Xi et al., 2005). Xi and coworkers use real-time confocal microscopy to detect the fluorescence emitted from DNA and PNA molecular beacons in microfluidic systems.

\section{Molecular imprint based recognition}

Molecular imprinting is a method for making selective binding sites in synthetic polymers using molecular templates. Molecular imprinted polymers offer great promise for development of very stable "solid-state like" artificial biosensing elements. In recent years, the technology of molecular imprinting has proliferated as an inexpensive, accessible and effective strategy for developing sorbent materials exhibiting high specificity for selected substrate materials. Shown in Fig. 10 is a generalized scheme describing synthesis of a molecular imprint receptor molecule. Although there are only a few examples of molecular imprint recognition element based biosensing, the possibility of imprinting against a wide range of analytes raises the possibility of generation of robust, artificial biological receptors making possible multiple clinical sample analysis without pretreatment, effectively reagentless chemistries. Molecular imprintquartz crystal microbalance detection is rapidly gaining acceptance for transducing the presence of a variety of analytes, especially glucose (Ersoz et al., 2005). Tai and coworkers (2005) have demonstrated recognition of Dengue viral protein using an epitope-mediated molecular imprinted film. This is significant since rapid diagnosis of this disease with high accuracy is crucial especially in light of the current diagnostic methodologies that are time and labor intensive and the lack of effective vaccines and drugs for treatment.

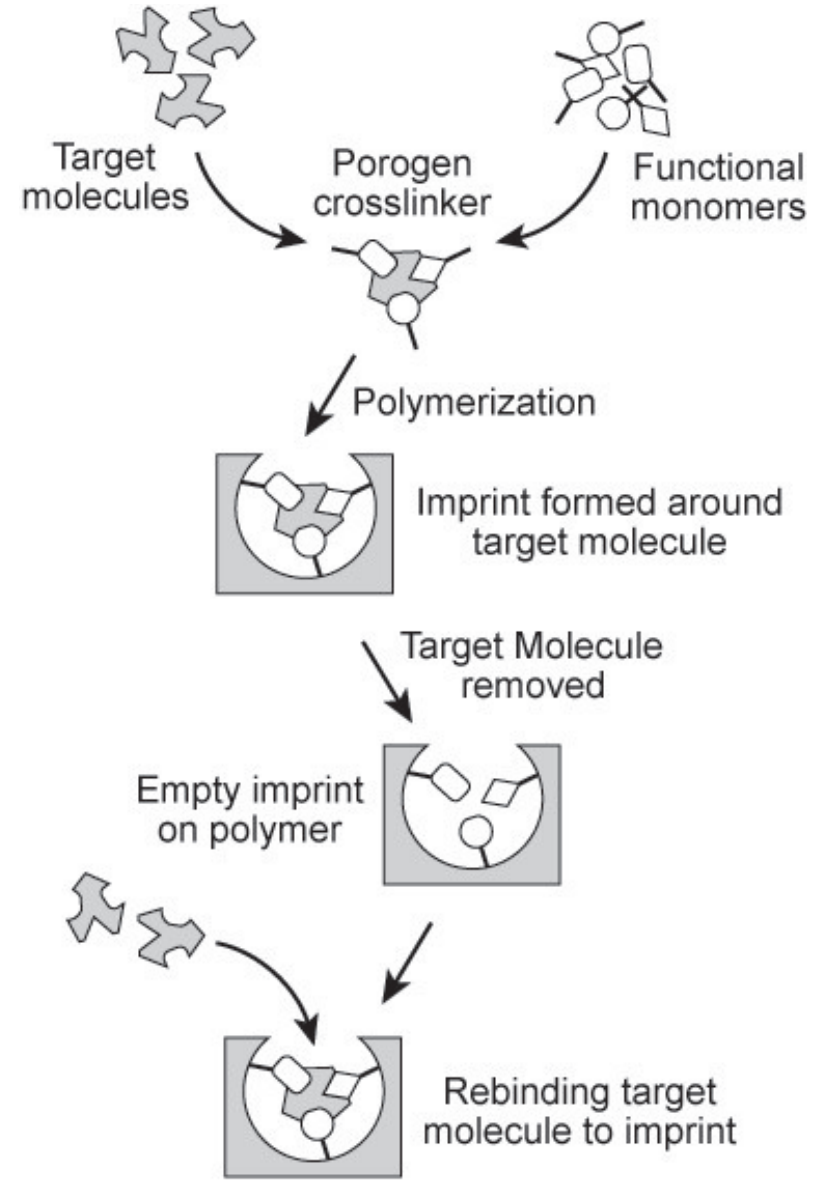

Fig. 10 Schematic representation of the preparation of molecular imprints.

\section{Lectin based recognition}

Lectins constitute a broad family of proteins involved in diverse biological processes, occasionally having potent toxic properties. Lectins generally exhibit strong binding to specific carbohydrate moieties known as glycans, and this property has been extensively exploited as a basis for biosensor design (Kim et al., 1990). Furthermore, particular structural profiles of glycans and their recognition by lectins have been attributed to disease progression, making analysis of saccharide-lectin binding processes important as a diagnostic tool.

Lectins are excellent biorecognition elements due to high affinity for saccharide moieties via multivalent interactions arising from the spatial organization of oligosaccharide ligands. The selective binding of lectins to terminal carbohydrate moieties on cell surfaces and protein aggregates has been widely exploited (Bertozzi and Kiessling, 2001). Although there are many ligand specific lectins available for use as biosensor recognition elements, Concanavalin A (Con A) is one of the most widely used lectins for saccharide detection. Several schemes entailing coupling of Con A to fluorescent moieties have been employed for specific ligand detection using fluorescence. Due to the high specificity of lectin biorecognition elements, lectin based sensors have been made which take advantage of advanced fluorescence 
techniques such as FRET. As with other biorecognition elements, in the absence of bound saccharide ligand, binding between the lectin and labeled carbohydrate target allows high FRET efficiency. However, the fluorescence energy transfer is decreased upon displacement of the bound ligand by the carbohydrate analyte, thus facilitating sensing of the soluble saccharide.

Lectin biorecognition elements have been used in a number of biosensors including electrical-oscillation (Yoshikawa and Omochi, 1986), piezoelectric crystal oligosaccharide(Nagase etal.,2003)and microcalorimetric platforms (Gemeiner et al., 1998). An intriguing technique for development of new and potentially important sensors is based upon use of Langmuir-Blodgett films of fullerene-glycodendron conjugates (Cardullo et al., 1998). A novel saccharide "force fingerprinting" technique based on single-molecule imaging capabilities of Atomic Force Microscopy has been reported (Wong et al., 2002).

\section{Discussion and conclusions}

Despite the many technological advances in biosensor recognition element development, the enzyme biorecognition element mediated glucose sensor dominates the current world market. The domination of biorecognition by this one major analyte arises primarily from the prevalence of diabetes in developed nations, emphasizing further that biorecognition element based sensing is expensive and must consider the development costs and the size of the target market to be served.

In the coming decade, the ability to "recognize" and "detect" electrically and magnetically will be radically transformed. The emergence of magnetoelectronics is a promising new platform technology for biorecognition element/sensor development (Prinz, 1998). Although the current prototypes have been directed at detection of biological warfare agents of great strategic and clinical relevance such as Bacillus anthracis, Yersinia pestis, Brucella suis, Francisella tularensis, Vibrio cholerae, Clostridium botulinum, Campylobacter jejuni and Vaccinia virus, a first generation magnoresistive biorecognition element based on spin valve sensors (Graham et al., 2004) is now being developed for diagnostic biochip detection of cystic fibrosis.

Nanotechnology is now making possible development of in vivo sensors, i.e. nano-sized devices envisioned to be ingested or injected where they could act as reporters of in vivo concentrations of key analytes (LaVan et al., 2003). These engineered nanoparticle devices imbedded in the cytosol of individual tissue specific cells will be capable of transmitting recognition events, that is, the binding to biorecognition elements of target analytes of clinical relevance to an external data capture system. Nanosensors will enable compartmental analyses of metabolite levels and metabolic activity which will drive "diagnostic methodologies." Nanosensor prototypes have been expressed in Yeast and in mammalian cell cultures for determination of carbohydrate homeostasis in living cells with subcellular resolution (Fehr et al., 2005). Nanosensors can be selectively expressed under the control of tissue specific promoters. The clinical relevance arising from constant, real-time metabolic vigilance via sensor based ligand specific biorecognition elements is immense. Virus-based nanoparticles have been developed for tumor specific recognition, targeting, imaging and destruction.

Of particular note, DNA conjugate materials have been prepared which can recognize DNA fragments with one-base specificity (Sprintz, 2004) for reliable genotyping of single nucleotide polymorphisms, while bacterial magnetic particles have been integrated into functional nanomaterials by assembling enzymes, antibodies and receptors onto nano-sized bacterial magnetic particles for use in applications such as determination of human insulin (Sprintz, 2004).

The emerging ability to control patterns of matter on the nanometer length scale can be expected to lead to entirely new spatial positioning schemes of biorecognition elements using a variety of new materials. Although current technologies such as microstructure fabrication, surface modification, integration of detection and optimization of chemistry can not effectively complete with current, wellestablished detection instrumentation, the need for high throughput diagnostic/detection methods will continue. If pursued, array technology should open the door for commercializing sensor platforms utilizing a variety of biorecognition elements for general diagnostic/detection purposes.

\section{References}

Bambot, S.B., Rao, G., Romauld, M., Carter, G.M., Sipior, J., Terpetchnig, E., and Lakowicz, J.R. (1995). Sensing oxygen through skin using a red diode laser and fluorescence lifetimes. Biosens. Bioelectron. 10, 643-652.

Barhoumi, A.H., Maaref, A., Rammah, M., Martelet, C., Jaffrezic, N., Mousty, C., Vial, S., and Forano, C. (2006). Urea biosensor based on $\mathrm{Zn}_{3} \mathrm{Al}$-Urease layered double hydroxides nanohybrid coated on insulated silicon structures. Materials Science and Engineering C. 26, 328-333.

Benhar, I., Eshkenazi I., Neufeld, T., Opatowsky, J., Shaky, S., and Rishpon, J. (2001). Recombinant single chain antibodies in bioelectrochemical sensors. Talanta 55, 899-907.

Bertozzi, C.R., and Kiessling, L.L. (2001). Chemical Glycobiology. Science 291, 2357-2364.

Brandt, O., and Hoheisel, J.D. (2004). Peptide nucleic acids on microarrays and other biosensors. Trends Biotechnol. 22, 617-622.

Cardullo, F., Diederich, F., Echegoyen, L., Habicher, T., Jayaraman, N., Leblanc, R.M., Stoddart, J.F., and Wang, S. (1998). Stable Langmuir and LangmuirBlodgett films of fullerene-glycodendron conjugates. Langmuir 14, 1955-1959.

Chakrabarti, R., and Klibanov, A.M. (2003). Nanocrystals modified with peptide nucleic acids (PNAs) for selective self-assembly and DNA detection. J. Am. Chem. Soc. 125, 12531-12540.

Demidov, V.V., Potaman, V.N., Frank-Kamenetskil, M.D., Egholm, M., Buchard, O., Sonnichsen, S.H., and Nielsen, P.E. (1994). Stability of peptide nucleic acids in human serum and cellular extracts. Biochem. Pharmacol. 48, 1310-1313. 
Doi, N. and Yanagawa, H. (1999). Design of generic biosensors based on green fluorescent proteins with allosteric sites by directed evolution. FEBS 453, 305307.

Egholm, M., Buchardt, O., Christensen, L., Behrens, C., Freier, S.M., Driver, D.A., Berg, R.H., Kim, S.K., Norden, B., and Nielsen, P.E. (1993). PNA hybridizes to complementary oligonucleotides obeying the WatsonCrick hydrogen-bonding rules. Nature 365, 566-568.

Ellington, A.D., and Szostak, J.K. (1990). In vitro selection of RNA molecules that bind specific ligands. Nature 346, 818-822.

Emanuel, P.A., Dang, J., Gebhardt, J.S., Aldrich, J., Garber, E.A.E., Kulaga, H., Stopa, P., Valdes, J.J., and Dion-Schultz, A. (2000). Recombinant antibodies: a new reagent for biological agent detection. Biosens. Bioelectron. 14, 751-759.

Ersoz, A., Denizli, A., Ozcan, A., and Say, R. (2005). Molecularly imprinted ligand-exchange recognition assay of glucose by quartz crystal microbalance. Biosens. Bioelectron. 20, 2197-2202.

Fehr, M., Okumoto, S., Deuschle, K., Lager, I., Looger, L.L., Persson, J., Kozhukh, L., Lalonde, S., and Frommer, W.B. (2005). Development and use of fluorescent nanosensors for metabolite imaging in living cells. Biochem. Soc. Trans. 33, 287-290.

Feltus, A., and Daunert, S. (2002). Genetic engineering of signaling molecules. In: Ligler, F.S., Rowe-Taitt, C.A. (Eds), Optical Biosensors: Present and Future. Elsevier, Amsterdam, pp. 307-329.

Ferrer-Miralles, N., Feliu, J.X., Vandevuer, S., Muller, A., Cabrera-Crespo, J., Ortmans, I., Hoffmann, F., Cazorla, D., Rinas, U., Prevost, M., and Villaverde, A. (2001). Engineering regulable Escherichia coli $\beta$-galactosidases as biosensors for anti-HIV antibody detection in human sera. J. Biol. Chem. 276, 40087-40095.

Gemeiner, P., Docolomansky, P., Vikartovska, A., and Stefuca, V. (1998). Amplification of flow-microcalorimetry signal by means of multiple bioaffinity layering of lectin and glycoenzyme. Biotechnol. Appl. Biochem. 28, 155161.

Graham, D.L., Ferreira, H.A., and Freitas, P.P. (2004). Magnetoresistive-based biosensors and biochips. Trends Biotechnol. 22, 455-462.

Gronewold, T.M.A., Glass, S., Quandt, E., and Famulok, M. (2005). Monitoring complex formation in the bloodcoagulation cascade using aptamer-coated SAW sensors. Biosens. Bioelectron. 20, 2044-2052.

Gulliksen, A., Solli, L., Karlsen, F., Rogne, H., Hovig, E., Nordstrom, T., and Sirevag, R. (2004). Real-time nucleic acid sequence-based amplification in nanoliter volumes. Anal. Chem. 76, 9-14.

Hansen, K.M., Ji, H.-F., Wu, G., Datar, R., Cote, R., Majumdar, A., and Thundat, T. (2001). Cantilever-based optical deflection assay for discrimination of DNA singlenucleotide mismatches. Anal. Chem. 73, 1567-1571.

Heller, A. (1990). Electrical wiring of redox enzymes. Acc. Chem. Res. 23, 128-134.

Heller, A. (1999). Implanted electrochemical glucose sensors for the management of diabetes. Annu. Rev. Biomed. Eng. 1, 153-175.
Hesselberth, J.R., Robertson, M.P., Knudsen, S.M., and Ellington, A.D. (2003). Simultaneous detection of diverse analytes with an aptazyme ligase array. Anal. Biochem. 312, 106-112.

Hirsch, L.R., Jackson, J.B., Lee, A., Halas, N.J., and West, J.L. (2003). A whole blood immunoassay using gold nanoshells. Anal. Chem. 75, 2377-2381.

Hitt, E. (2004). Label-free methods are not problem free. Drug Discov. Devel. 7, 34-42.

Igloi, G. (1998). Variability in the stability of DNA-peptide nucleic acid (PNA) single-base mismatched duplexes: real-time hybridization during affinity electrophoresis in PNA containing gels. Proc. Natl Acad. Sci. USA 95, 8562-8567.

Jayasena, S. D. (1999). Aptamers: An emerging class of molecules that rival antibodies in diagnostics. Clinical Chemistry. 45, 1628-1650.

Jiang, Y., Fang, X., and Bai, C. (2004). Signaling aptamer/ protein binding by a molecular light switch complex. Anal. Chem. 76, 5230-5235.

Kim, B., Cha, G.S., Meyerhoff, M. E. (1990). Homogeneous enzyme-linked binding assay for studying the interaction of lectins with carbohydrates and glycoproteins. Anal. Chem. 62, 2663-2668.

Kirby, R., Cho E.J., Gehrke, B., Bayer, T., Park, Y.S., Neikirk, D.P., McDevitt, J.T., and Ellington, A.D. (2004). Aptamer-based sensor arrays for the detection quantitation of proteins. Anal. Chem. 76, 4066-4075.

Koh, C.G., Tan, W., Zhao, M.-Q., Ricco, A.J., and Fan, Z.H. (2003). Integrating polymerase chain reaction, valving, and electrophoresis in a plastic device for bacterial detection. Anal. Chem. 75, 4591-4598.

Krishna, G., Schulte, J., Cornell, B.A., Pace, R.J., and Osman, P.D. (2003). Tethered bilayer membranes containing ionic reservoirs: selectivity and conductance. Langmuir 19, 2294-2305.

LaVan, D.A., McGuire, T., and Langer, R. (2003). Small-scale systems for in vivo drug delivery. Nature Biotechnol. 21, 1184-1191.

Lee, M., and Walt, D. R. (2000). A fiber-optic microarray biosensor using aptamers as receptors. Anal. Biochem. 282, 142-146.

Lim, D.V., Simpson, J.M, Kearns, E.A. and Kramer, M.F. (2005). Current and developing technologies for monitoring agents of bioterrorism and biowarfare. Clin. Microbiol. Rev. 18, 583-607.

Liss, M., Petersen, B., Wolf, H., and Prohaska, E. (2002). An aptamer-based quartz crystal protein biosensor. Anal. Chem. 74, 4488-4495.

Luzi, E., Minunni, M., Tombelli, S., and Mascini, M. (2003). New trends in affinity sensing - aptamers for ligand binding. Trends in Analytical Chem. 22, 810-818.

McCauley, T.G., Hamaguchi, N., and Stanton, M. (2003). Aptamer-based biosensor arrays for detection and quantification of biological micromolecules. Anal. Biochem. 319, 244-250.

Mano, N., and Heller, A. (2005). Detection of glucose at 2 fM concentration. Anal. Chem. 77, 729-732.

Minunni, M., Tombelli, S., Gullotto, A., Luzi, E., and Mascini, M. (2004). Development of biosensors with aptamers as bio-recognition element: the case of HIV-1 Tat protein. Biosens. Bioelectron. 20, 1149-1156. 
Nagase, T., Nakata, E., Shinkai, S., and Hamachi, I. (2003). Construction of artificial signal transducers on a lectin surface by post-photoaffinity-labeling modification for fluorescent saccharide biosensors. Chemistry 9 , 3660-3669.

Nakamura, H. and Karube, I. (2003). Current research activity in biosensors. Anal. Bioanal. Chem. 377, 446468.

Niemeyer, C.M., Adler, M., and Wacker, R. (2005). Immuno-PCR: high sensitivity detection of proteins by nucleic acid amplification. Trends Biotechnol. 23, 208216.

Nutiu, R., and Li, Y. (2004). Structure-switching signaling aptamers. J. Am. Chem. Soc. 125, 4771-4778.

O'Brien, M.J., Perez-Luna, V.H., Brueck, S.R., and Lopez, G.P. (2001). A surface plasmon resonance array biosensor based on spectroscopic imaging. Biosens. Bioelectron. 16, 97-108.

O'Connell, P., and Guilbault, G. (2001). Future trends in biosensor research. Analytical Letters 34(7), 10631078.

Petrenko, V.A., and Sorokulova, I.B. (2004). Detection of biological threats. A challenge for directed molecular evolution. J. Mic. Meth. 58, 147-168.

Pieken, W.A., Olsen, D.B., Benseler, F., Aurup, H., and Eckstein, H.F. (1991). Kinetic characterization of ribonuclease-resistant 2'-modified hammerhead ribozymes. Science 253, 314-317.

Prinz, G.A. (1998). Magnetoelectronics. Science 282, 1660-1663.

Rajendran, M., and Ellington, A.D. (2002). Nucleic acids for reagentless biosensors. In: Optical Biosensors: Present and Future. Ligler and Taitt Eds., pp. 369-396.

Roe, J.N., and Smoller, B.R. (1998). Bloodless glucose measurements. Crit. Rev. Ther. Drug Carrier Syst. 15, 199-241.

Sano, T., Smith, C.L., and Cantor, C.R. (1992). ImmunoPCR: very sensitive antigen detection by means of specific antibody-DNA conjugates. Science 258, 120 122.

Savran, C.A., Knudsen, S.M., Ellington, A.D., and Manalis, S.R. (2004). Micromechanical detection of proteins using aptamer-based receptor molecules. Anal. Chem. 76, 3194-3198.

Schultz, J.S., and Sims, G. (1979). Affinity sensors for individual metabolites. Biotech. Bioeng. Symp. 9, 6571.

Scognamiglio, V., Staiano, M., Rossi, M., and D'Auria, S. (2004). Protein-based biosensors for diabetic patients. J. Fluores. 14, 491-498.

Sprintz, M. (2004). Nanotechnology for advanced therapy and diagnosis. Biomed. Microdevices 6, 101-103.

Stadtherr, K., Wolf, H., and Lindner, P. (2005). An aptamerbased protein biochip. Anal. Chem. 77, 3437-3443.

Stojanovic, M.N., and Landry, D.W. (2002). Aptamerbased colorimetric probe for cocaine. J. Am. Chem. Soc. 124, 9678-9679.

Subrahmanyam, S., Piletsky, S.A., and Turner, A.P.F. (2002). Application of natural receptors in sensors and assays. Anal. Chem. 74, 3942-3952.
Tai, D.-F., Lin, C.-Y., Wu, T.-Z., and Chen, L.-K. (2005). Recognition of Dengue virus protein using epitopemediated molecularly imprinted film. Anal. Chem. 77, 5140-5143.

Tang, Y., Fang, J., Xu, X., Ji, H.-F., Brown, G.M., and Thundat, T. (2004). Detection of femtomolar concentrations of $\mathrm{HF}$ using an $\mathrm{SiO}_{2}$ microcantilever. Anal. Chem. 76, 2478-2481.

Tuerk, C., and Gold, L. (1990). Systematic evolution of ligands by exponential enrichment: RNA ligands to bacteriophage T4 DNA polymerase. Science 249 , 505510.

Turner, A.P. (2000). Biosensors - sense and sensitivity. Science 290, 1315-1317.

Tyagi, S., and Kramer, F.R. (1996). Molecular beacons: probes that fluoresce upon hybridization. Nature Biotechnol. 14, 303-308.

Updike, S.J., and Hicks, G.P. (1967). The enzyme electrode. Nature 214, 986-988.

Valdes, J.J., Wall, J.G., Chambers, J.P. and Eldefrawi, M.E. (1988). A receptor-based capacitive biosensor. The Johns Hopkins University Applied Physics Laboratory Technical Digest 9, 4-10.

Valdes, J.J., Rogers, K., and Eldefrawi, M.F. (1990). Detection of natural toxins by an acetylcholine receptor optical sensor. $156^{\text {th }}$ National Meeting of the American Association for the Advancement of Science; New Orleans, LA. pp. 15-20.

Wang, H., Li, J., Liu, H., Liu, Q., Wang, Y., Zhu, J., He, N., and Lu, Z. (2002). Label-free hybridization detection of a single nucleotide mismatch by immobilization of molecular beacons on an agarose film. Nucleic Acids Res. 30, e61.

Wang, J., and Zhang, X. (2001). Needle-type dual microsensor for the simultaneous monitoring of glucose and insulin. Anal. Chem. 73, 844-847.

Wang, J., Chatrathi, M.P., Tian, B., and Polsky, R. (2000). Microfabricated electrophoresis chips for simultaneous bioassays of glucose, uric acid, ascorbic acid, and acetominophen. Anal. Chem. 72, 2514-2518.

Wong, N.K.C., Kanu, N., Thandrayen, N., Rademaker, G.J., Baldwin, C.I., Renouf, D.V., and Hounsell, E.F. (2002) Microarray analyses of protein glycosylation. In: Protein Protocols Handbook, $2^{\text {nd }}$ ed. 841-850.

Wu, G., Ji, H., Hansen, K., Thundat, T., Datar, R., Cote, R., Hagan, M.F., Chakraborty, A.K., and Majumdar, A. (2001). Origin of nanomechanical cantilever motion generated from biomolecular interactions. Proc. Natl Acad. Sci. USA 98, 1560-1564.

Xi, C., Balberg, M., Boppart, S.A., and Raskin, L. (2003). Use of DNA and peptide nucleic acid molecular beacons for detection and quantitation of rRNA in solution and in whole cells. Appl. Environ. Microbiol. 69, 5673-5678.

Xi, C., Raskin, L., and Boppart, S.A. (2005). Evaluation of microfluidic biosensor development using microscopic analysis of molecular beacon hybridization kinetics. Biomed. Microdevices 7, 7-12.

Yamaguchi, H. and Harada, A. (2003). Antibody Dendrimers. Top Curr Chem. 228, 237-258. 
Yamazaki, T., Kojima, K., and Sode, K. (2000). Extendedrange glucose sensor employing engineered glucose dehydrogenases. Anal. Chem. 72, 4689-4693.

Yan, X., Xu, X. K., and Ji, H.-F. (2005). Glucose oxidase multilayer modified microcantilevers for glucose measurement. Anal. Chem. 77, 6197-6204.
Yoshikawa, K., and Omochi, T. (1986). Chemical sensing by a novel electrical oscillator: detection and quantitation of polysaccharides in concanavalin A solutions. Biochem. Biophys. Res. Commun. 137, 978-983.

Zhang, M., Mullens, C., and Gorski, W. (2005). Insulin oxidation and determination at carbon electrodes. Anal. Chem. 77, 6396-6401. 


\section{Further Reading}

Caister Academic Press is a leading academic publisher of advanced texts in microbiology, molecular biology and medical research. Full details of all our publications at caister.com

- MALDI-TOF Mass Spectrometry in Microbiology Edited by: M Kostrzewa, S Schubert (2016) www.caister.com/malditof

- Aspergillus and Penicillium in the Post-genomic Era Edited by: RP Vries, IB Gelber, MR Andersen (2016) www.caister.com/aspergillus2

- The Bacteriocins: Current Knowledge and Future Prospects Edited by: RL Dorit, SM Roy, MA Riley (2016)

www.caister.com/bacteriocins

- Omics in Plant Disease Resistance Edited by: V Bhadauria (2016) www.caister.com/opd

- Acidophiles: Life in Extremely Acidic Environments Edited by: R Quatrini, DB Johnson (2016) www.caister.com/acidophiles

- Climate Change and Microbial Ecology: Current Research and Future Trend

Edited by: J Marxsen (2016)

www.caister.com/climate

- Biofilms in Bioremediation: Current Research and Emerging Technologies

Edited by: G Lear (2016)

www.caister.com/biorem

- Microalgae: Current Research and Applications Edited by: MN Tsaloglou (2016) www.caister.com/microalgae

- Gas Plasma Sterilization in Microbiology: Theory, Applications, Pitfalls and New Perspectives Edited by: H Shintani, A Sakudo (2016) www.caister.com/gasplasma

- Virus Evolution: Current Research and Future Directions Edited by: SC Weaver, M Denison, M Roossinck, et al. (2016) www.caister.com/virusevol

- Arboviruses: Molecular Biology, Evolution and Control Edited by: N Vasilakis, DJ Gubler (2016) www.caister.com/arbo

- Shigella: Molecular and Cellular Biology Edited by: WD Picking, WL Picking (2016) www.caister.com/shigella

-Aquatic Biofilms: Ecology, Water Quality and Wastewater Treatment

Edited by: AM Romaní, H Guasch, MD Balaguer (2016)

www.caister.com/aquaticbiofilms

- Alphaviruses: Current Biology

Edited by: S Mahalingam, L Herrero, B Herring (2016)

www.caister.com/alpha

- Thermophilic Microorganisms

Edited by: F Li (2015)

www.caister.com/thermophile
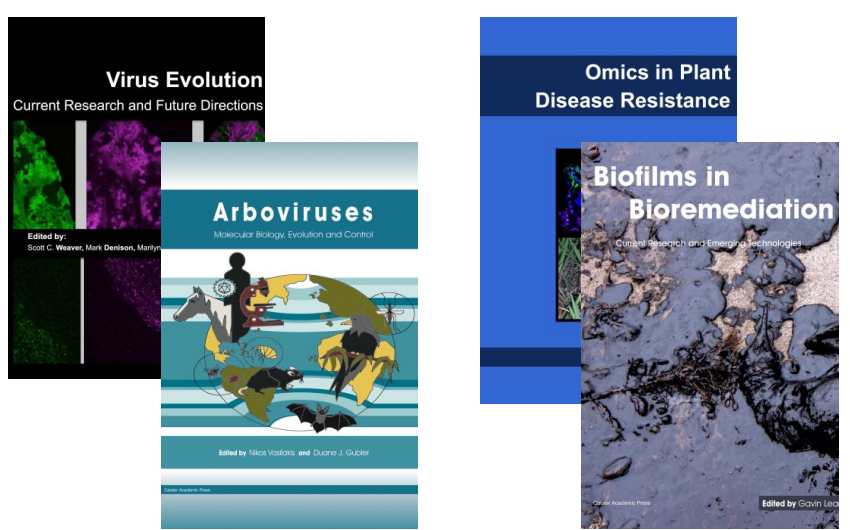
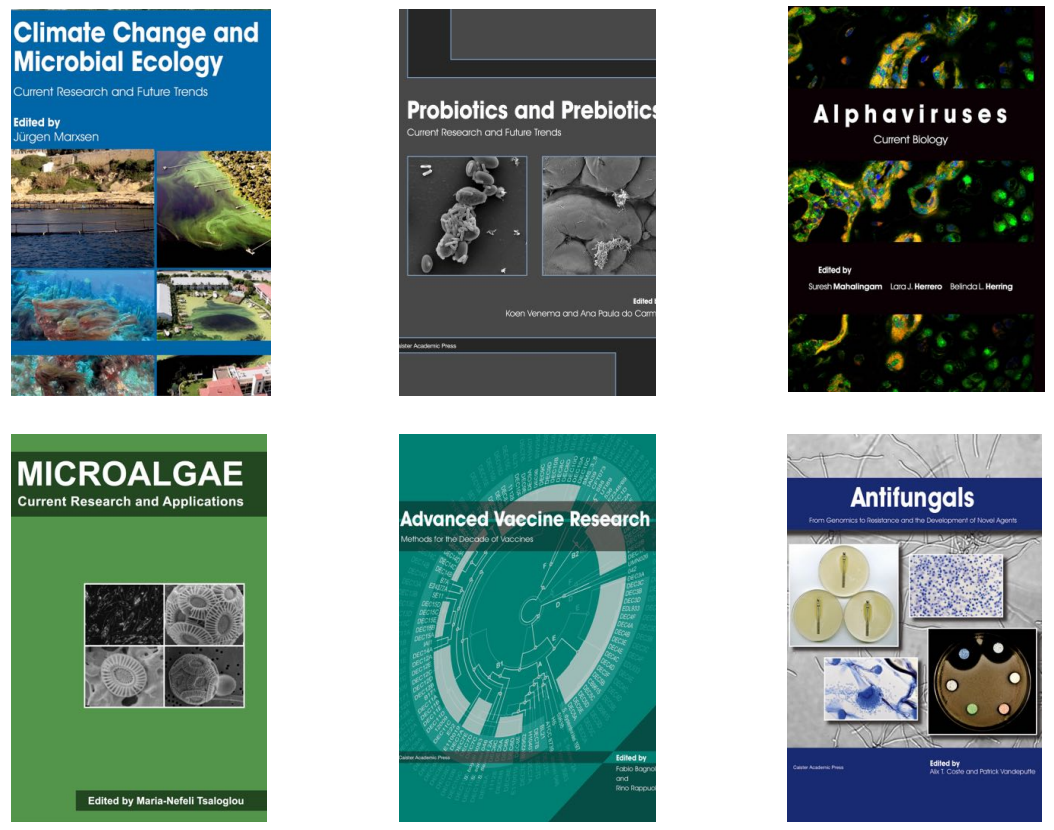

- Flow Cytometry in Microbiology: Technology and Applications Edited by: MG Wilkinson (2015) www.caister.com/flow

- Probiotics and Prebiotics: Current Research and Future Trends Edited by: K Venema, AP Carmo (2015) www.caister.com/probiotics

- Epigenetics: Current Research and Emerging Trends Edited by: BP Chadwick (2015) www.caister.com/epigenetics2015

- Corynebacterium glutamicum: From Systems Biology to Biotechnological Applications

Edited by: A Burkovski (2015)

www.caister.com/cory2

- Advanced Vaccine Research Methods for the Decade of Vaccines

Edited by: F Bagnoli, R Rappuoli (2015)

www.caister.com/vaccines

- Antifungals: From Genomics to Resistance and the Development of Novel Agents

Edited by: AT Coste, P Vandeputte (2015)

www.caister.com/antifungals

- Bacteria-Plant Interactions: Advanced Research and Future Trends Edited by: J Murillo, BA Vinatzer, RW Jackson, et al. (2015) www.caister.com/bacteria-plant

\section{- Aeromonas}

Edited by: J Graf (2015)

www.caister.com/aeromonas

- Antibiotics: Current Innovations and Future Trends

Edited by: S Sánchez, AL Demain (2015)

www.caister.com/antibiotics

- Leishmania: Current Biology and Contro Edited by: S Adak, R Datta (2015) www.caister.com/leish2

- Acanthamoeba: Biology and Pathogenesis (2nd edition) Author: NA Khan (2015)

www.caister.com/acanthamoeba2

- Microarrays: Current Technology, Innovations and Applications Edited by: Z He (2014)

www.caister.com/microarrays2

- Metagenomics of the Microbial Nitrogen Cycle: Theory, Methods and Applications

Edited by: D Marco (2014)

www.caister.com/n2 